\title{
CRYSTAL STRUCTURE AND DFT STUDIES OF 4-(1-BENZYL-5-METHYL-1H-1,2,3-TRIAZOL-4-YL)-6-(3- METHOXYPHENYL)PYRIMIDIN-2-AMINE
}

\author{
S. MURUGAVEL ${ }^{1 *}$, S. VIJAYAKUMAR ${ }^{2}$, SANGARAIAH NAGARAJAN ${ }^{3}$, ALAGUSUNDARAM PONNUSWAMY \\ ${ }^{1}$ Department of Physics, Thanthai Periyar Government Institute of Technology, Vellore-632 002, Tamilnadu, India \\ ${ }^{2}$ Department of Physics, Sri Balaji Chokkalingam Engineering College, Arni, Thiruvannamalai - 632 317, Tamilnadu, India \\ ${ }^{3}$ Department of Organic Chemistry, School of Chemistry, Madurai Kamaraj University, Madurai-625021, Tamilnadu, India
}

\begin{abstract}
The title compound 1, 4-(1-benzyl-5-methyl-1H-1,2,3-triazol-4-yl)-6-(3-methoxyphenyl)pyrimidin-2-amine $\left(\mathrm{C}_{21} \mathrm{H}_{20} \mathrm{~N}_{6} \mathrm{O}\right)$, was synthesized and structurally characterized by elemental analysis, ${ }^{1} \mathrm{H}$ NMR, ${ }^{13} \mathrm{C}$ NMR and single crystal X-ray diffraction. The molecular conformation is stabilized by an intramolecular $\mathrm{C}-\mathrm{H} . . . \mathrm{N}$ hydrogen bond, which generates an $\mathrm{S}(6)$ ring motif. In the crystal, molecules are linked by two pairs of inversion-related amine $\mathrm{N}-\mathrm{H}$, , ${ }^{\mathrm{N}}$ and $\mathrm{C}-\mathrm{H}$, , . $\mathrm{N}$ hydrogen bonds, each generating alternate $R_{2}^{2}(8)$ ring motifs in a zigzag supramolecular chain that runs along $c$-axis. These chains stack along $a$-axis via amine $\mathrm{N}-\mathrm{H}$... O hydrogen bonds forming a two-dimensional supramolecular network. Density functional theory calculations of the structure, Mulliken population analyses on atomic charges and thermodynamic functions of the title compound were performed by using (DFT/B3LYP) method with the 6-311G(d,p) basis set level. The charge energy distribution and site of chemical reactivity of molecules were obtained by mapping electron density isosurface with electrostatic potential surfaces. The thermo dynamical properties of the title compound at different temperature have been calculated and corresponding relations between the properties and temperature have also been obtained.
\end{abstract}

Key Words: X-ray structure determination; Hydrogen bonds; DFT calculations; HOMO-LUMO; MEP.

\section{INTRODUCTION}

1,2,3-triazoles found to have wide range of important applications in the pharmaceutical, polymer, and material fields ${ }^{1}$. In addition, they have shown a broad spectrum of biological properties such as anti-bacterial ${ }^{2}$ anti-allergic ${ }^{3}$, anti-HIV activity ${ }^{4}$ and also serve as potential chemotherapeutic agents for various diseases ${ }^{5}$. On the other hand, substituted pyrimidine nuclei are found antiviral ${ }^{6}$, anti-tubercular, antineoplastic, anti-inflammatory, diuretic, antimalarial and cardiovascular? ${ }^{7}$. In view of these bioactivities of the individual heterocycles, it was envisaged that the synthesis of novel hybrid molecules containing two of the above said moieties in a single frame is worth to attempt. Literature survey reveals that so for there is no experimental and theoretical study for the title compound. In recent years, density functional theory (DFT) has become an increasingly useful tool for theoretical studies. The success of DFT is mainly due to the fact that it describes small molecules more reliably than Hartree-Fock theory. It is also computationally less demanding than wave function based methods with inclusion of electron correlation ${ }^{8-9}$. Thus, in order to characterize the correlation between molecular structure and macroscopic properties in the studied compound, it seems to be essential to undertake a detailed comparative study of the isolated molecule and the solid state unit. In this paper, a concerted approach by X-ray crystallography and DFT calculation was used, which takes advantage of both the high interpretative power of the theoretical studies and the precision and reliability of the experimental method.

The title compound has been synthesized and antibacterial activities are reported by our co-authors ${ }^{10}$. In this paper, we report the synthesis, crystal structure of 4-(1-benzyl-5-methyl-1H-1,2,3-triazol-4-yl)-6-(3-methoxyphenyl) pyrimidin-2-amine $\left(\mathrm{C}_{21} \mathrm{H}_{20} \mathrm{~N}_{6} \mathrm{O}\right)$, as well as theoretical studies using the DFT(B3LYP) method and $6-311 \mathrm{G}(\mathrm{d}, \mathrm{p})$ basis set. The aim of the present work was to describe and characterize the molecular structure and some electronic structure properties of the title compound, both experimentally and theoretically. Also, chemical reactivity values such as chemical hardness, chemical potential electronegativity and electrophilicity index and HomoLumo energy gap obtained theoretically can be used to understand the biological activity of the title compound.

\section{EXPERIMENTAL AND COMPUTATIONAL METHODS}

\subsection{Synthesis of 1}

The title compound 1 was obtained according to the reaction scheme 1. A mixture of (E)-1-(1-benzyl-5-methyl-1H-1,2,3-triazol-4-yl)-3-(3methoxyphenyl)prop-2-en-1-one $(0.2 \mathrm{~g}, 0.59 \mathrm{mmol})$, guanidine hydrochloride $(0.17 \mathrm{~g}, 1.77 \mathrm{mmol})$ and $\mathrm{NaOH}(0.04 \mathrm{~g}, 1.0 \mathrm{mmol})$ in ethanol $(10 \mathrm{~mL})$ was refluxed for $40 \mathrm{~min}$. Then, the reaction mixture was poured onto excess crushed ice and neutralized with dilute hydrochloric acid. The precipitated 4-(1-benzyl5-methyl-1H-1,2,3-triazol-4-yl)-6-(3-methoxyphenyl)pyrimidin-2-amine was filtered and recrystallized from ethano $1^{10}$. Needle like colourless single crystals of the title compound used in X-ray diffraction studies were grown in an ethanolic solution by slow evaporation of the solvent at room temperature and collected in $78 \%$ yield.

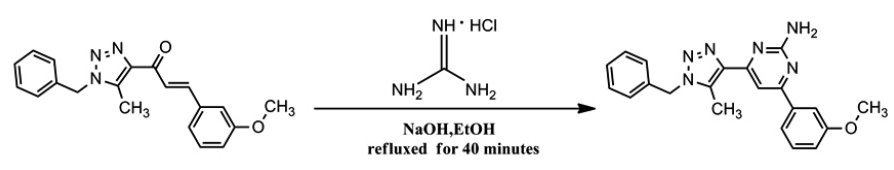

Scheme 1: Synthesis of 4-(1-benzyl-5-methyl-1H-1,2,3-triazol-4-yl)-6-(3methoxyphenyl)pyrimidin-2-amine

The Nuclear magnetic resonance spectra $\left({ }^{1} \mathrm{H}\right.$ NMR and ${ }^{13} \mathrm{C}$ NMR) were recorded in $\mathrm{CDCl}_{3}$ and DMSO- $\mathrm{d}_{6}$ on Bruker Advance $300 \mathrm{MHz}$ spectrometer and the chemical shifts are reported as $\delta$ values in parts per million (ppm) relative to tetramethylsilane, with $J$ values in Hertz. The splitting patterns in ${ }^{1} \mathrm{H}$ NMR spectra are reported as follows: $\mathrm{s}=$ singlet; $\mathrm{d}=$ doublet; $\mathrm{br} \mathrm{s}=$ broad singlet; br $\mathrm{d}=$ broad doublet; $\mathrm{m}=$ multiplet. ${ }^{13} \mathrm{C}$ NMR data are reported with the solvent peak $\left(\mathrm{CDCl}_{3}=77.0 \mathrm{MHz}\right)$ as the internal standard.

White solid; m.p. $59^{\circ} \mathrm{C}$, Yield: $78 \%$; ${ }^{1} \mathrm{H}$ NMR $\left(300 \mathrm{MHz}, \mathrm{CDCl}_{3}\right): \delta 7.96$ $(1 \mathrm{H}, \mathrm{s},=\mathrm{CH}), 7.66(2 \mathrm{H}, \mathrm{m}, \mathrm{ArH}), 7.37-7.00(7 \mathrm{H}, \mathrm{m}, \mathrm{ArH}), 5.54\left(2 \mathrm{H}, \mathrm{s}, \mathrm{C}_{6} \mathrm{H}_{5}-\right.$ $\left.\mathrm{CH}_{2}\right), 5.18\left(2 \mathrm{H}\right.$, brs, $\left.\mathrm{NH}_{2}\right), 3.88\left(3 \mathrm{H}, \mathrm{s}, \mathrm{OCH}_{3}\right), 2.60\left(3 \mathrm{H}, \mathrm{s}, \mathrm{CH}_{3}\right) ;{ }^{13} \mathrm{C} \mathrm{NMR}$ $\left(75 \mathrm{MHz}, \mathrm{CDCl}_{3}\right): \delta 165.69,163.17,160.09,139.06,134.58,134.02,129.68$, $129.11,129.06,128.40,127.19,119.74,116.82,112.09,104.60,55.45,51.62$, 9.79 .

2.2 X-ray Crystallography

A Crystal of the title compound having approximate dimension $0.30 \times 0.25 \times 0.11 \mathrm{~mm}^{3}$ was mounted on a glass fiber using cyanoacrylate adhesive. All measurement were made on a Bruker AXS Kapppa Apex II single crystal X-ray diffractometer using graphite mono-chromated $\mathrm{MoK} \alpha(\lambda$ $=0.71071 \AA$ ) radiation and CCD detector. Diffraction data were collected at room temperature by the $\omega$-scan technique. Accurate unit cell parameters and orientation matrix were obtained by a least-squares fit of several high angle reflections in the ranges $2.17^{\circ}<\theta<26.00^{\circ}$ for the title compound. The unit cell parameters were determined for 36 frames measured $\left(0.5^{\circ} \mathrm{phi}-\mathrm{scan}\right)$ from three different crystallographic zones and using the method of difference vectors. The intensity data were collected with an average four-fold redundancy per reflection and optimum resolution $(0.75 \AA)$. The intensity data collection, frames integration, Lorentz-polarization correction and decay correction were done using SAINT-NT (version 7.06a) software. Empirical absorption 
correction (multi-scan) was performed using SADABS ${ }^{11}$ program. The structure was solved by direct methods using SHELXS-97 implemented in WinGX $\mathrm{X}^{12}$ program suit. The refinement was carried out by full-matrix leastsquare method on the positional and anisotropic temperature parameters of the non-hydrogen atoms, using SHELXL-97 ${ }^{13}$. All the $\mathrm{H}$ atoms were positioned geometrically and constrained to ride on their parent atom with $\mathrm{C}-\mathrm{H}=0.93-$ $0.97 \AA$ and $\mathrm{N}-\mathrm{H}=0.86 \AA$, and with $\mathrm{U}_{\text {iso }}(\mathrm{H})=1.5 \mathrm{U}_{\text {eq }}$ for methyl $\mathrm{H}$ atoms and $1.2 \mathrm{U}(\mathrm{C})$ for other $\mathrm{H}$ atoms. Owing to poor agreement, the reflections [ 1600$]$,

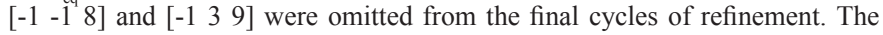
general-purpose crystallography tool PLATON ${ }^{14}$, ORTEP $^{15}$ and MERCURY ${ }^{16}$ were used for structure analysis and presentation of the results. Details of the data collection, crystal parameters and refinement process of compound 1 are given in Table 1.

Table 1 Crystal and experimental data for the compound 1

\begin{tabular}{|c|c|}
\hline Empirical formula & $\mathrm{C}_{21} \mathrm{H}_{20} \mathrm{~N}_{6} \mathrm{O}$ \\
\hline Formula weight & 372.43 \\
\hline Temperature (K) & 293(2) \\
\hline Wavelength $(\AA)$ & 0.71073 \\
\hline Crystal system & Triclinic \\
\hline Space group & P-1 \\
\hline \multicolumn{2}{|l|}{ Unit cell dimensions $\left(\AA,^{\circ}\right)$} \\
\hline$a$ & $6.2636(5)$ \\
\hline$b$ & $8.1120(5)$ \\
\hline C & $19.3287(1)$ \\
\hline$A$ & $79.409(3)$ \\
\hline$B$ & $81.268(4)$ \\
\hline$\gamma$ & $88.441(4)$ \\
\hline Volume $\left(\AA^{3}\right)$ & $954.18(1)$ \\
\hline$Z$ & 2 \\
\hline Calculated density $\left(\mathrm{Mg} / \mathrm{m}^{3}\right)$ & 1.296 \\
\hline Absorption coefficient $\left(\mathrm{mm}^{-1}\right)$ & 0.085 \\
\hline $\mathrm{F}(000)$ & 392 \\
\hline Crystal size $\left(\mathrm{mm}^{3}\right)$ & $0.30 \times 0.25 \times 0.11$ \\
\hline Theta range for data collection $\left({ }^{\circ}\right)$ & 2.17 to 26.00 \\
\hline Index ranges & $\begin{array}{l}-7<=\mathrm{h}<=7,-9<=\mathrm{k}<=10 \\
-23<=1<=23\end{array}$ \\
\hline Reflections collected & 17248 \\
\hline Independent reflections & $3703[\mathrm{R}(\mathrm{int})=0.0336]$ \\
\hline Completeness to theta $=26.00^{\circ}$ & $98.7 \%$ \\
\hline Refinement method & Full-matrix least-squares on $\mathrm{F}^{2}$ \\
\hline Data / restraints / parameters & $3703 / 0 / 255$ \\
\hline Goodness-of-fit on $\mathrm{F}^{2}$ & 1.138 \\
\hline Final $R$ indices $[\mathrm{I}>2 \sigma(\mathrm{I})]$ & $\mathrm{R} 1=0.0654, \mathrm{wR} 2=0.1946$ \\
\hline $\mathrm{R}$ indices (all data) & $\mathrm{R} 1=0.0749, \mathrm{wR} 2=0.2007$ \\
\hline Largest diff. peak and hole $\left(\mathrm{e} . \AA^{-3}\right)$ & 0.277 and -0.291 . \\
\hline
\end{tabular}

\subsection{Computational Details}

The molecular structure of the compound in ground state (in vacuo) was optimized using density functional theory DFT (B3LYP) $)^{17,18}$ method with the $6-311 \mathrm{G}(\mathrm{d}, \mathrm{p})^{19}$ basis set. All the calculation was performed without specifying any symmetry for the title molecule by using GaussView molecular visualization program ${ }^{20}$ and Gaussian 03 program package ${ }^{21}$. The optimized geometrical parameters, energy, atomic charges and dipole moments were calculated using Gaussian 03W package. GaussView 03 program has been using to construct optimized molecular geometry, Mullikan charges, HOMO, LUMO energy distributions and HOMO-LUMO energy gap ${ }^{22,23}$.

\section{RESULTS AND DISCUSSION}

\subsection{Description of Crystal structure}

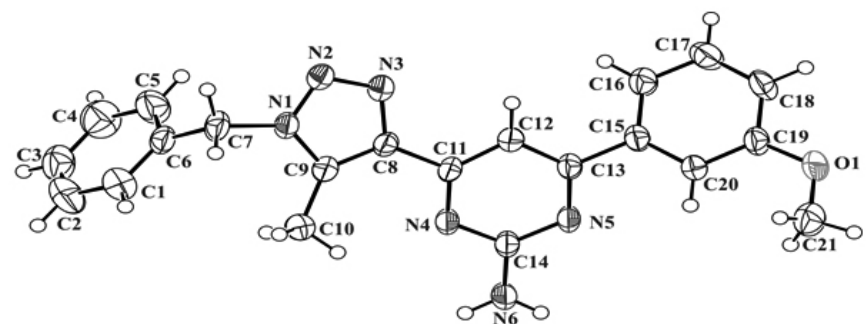

(a)

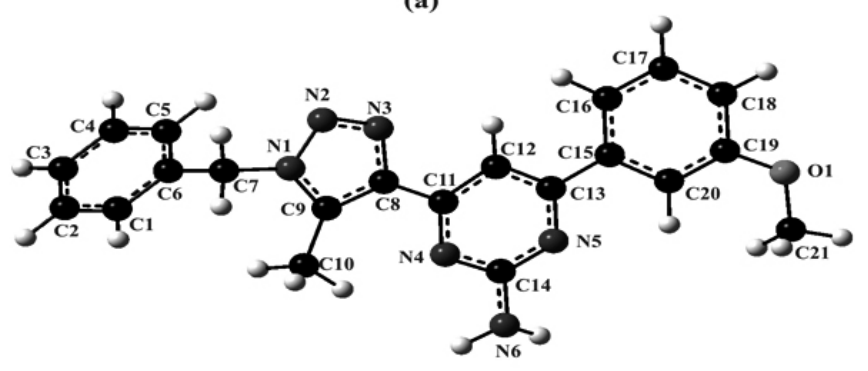

(b)

Figure 1: (a) View of title compound showing the atom-numbering scheme. Displacement ellipsoids for the non- $\mathrm{H}$ atoms are drawn at the $50 \%$ probability level. The $\mathrm{H}$ atoms are presented with spheres with arbitrary radii. (b) The theoretical geometric structure of the title compound (B3LYP/6$311 \mathrm{G}(\mathrm{d}, \mathrm{p})$ level $)$.

The displacement ellipsoid plot and theoretical geometry structure with the atom-numbering scheme for compound $\mathbf{1}$ is shown in Fig. 1. The compound crystallizes as a colourless needle shaped in the triclinic system, space group $\mathrm{P}$ -1 with cell constants: $a=6.2636(5) \AA, b=8.1120(5) \AA, c=19.3287(14) \AA, \alpha=$ $79.409(3)^{\circ}, \beta=81.268(4)^{\circ}, \gamma=88.441(4)^{\circ}, V=954.18(1) \AA^{3}, Z=2$.

The triazole $(\mathrm{N} 1 / \mathrm{N} 2 / \mathrm{N} 3 / \mathrm{C} 8 / \mathrm{C} 9)$ ring is essentially planar [maximum deviation $=0.001(3) \AA$ for the $\mathrm{C} 9$ atom] and forms dihedral angle of $17.8(1)^{\circ}$ with the pyrimidine ring. The methoxy phenyl ring attached to the pyrimidine ring is in bisectional position. The dihedral angle between the benzene ring and methoxy phenyl ring is $40.2(2)^{\circ}$. The bond distances $\mathrm{N} 3-\mathrm{C} 8, \mathrm{C} 8-\mathrm{C}$, C9-N1, N1-N2 and N2-N3 are 1.362(4), 1.375(4), 1.352(4), 1.345(3) and $1.299(3) \AA$, respectively, which agrees with $\mathrm{C}=\mathrm{C}, \mathrm{N}=\mathrm{N}, \mathrm{C}-\mathrm{N}$ distances found in literature for compound having triazole heterocycle ${ }^{24,25}$. In pyrimidine ring the $\mathrm{N}-\mathrm{C}$ bond lengths $[1.331(4)-1.345(3) \AA]$ and bond angles N6-C14$\mathrm{N} 4\left[116.0(2)^{\circ}\right]$ are found close to the reported values for similar pyrimidine derivatives ${ }^{26}$.

The hydrogen bond geometry for compound $\mathbf{1}$ is presented in Table 2 . The molecular conformation is stabilized by an intramolecular C10-H10B... $\mathrm{N} 4$ hydrogen bond, which generates a $\mathrm{S}(6)$ ring motif ${ }^{27}$. In the crystal, molecules are linked by two pairs of inversion-related N6-H6B, , .N5 and C7-H7A, . .N2 hydrogen bonds, each generating alternate $R_{2}^{2}(8)$ ring motifs in a zigzag supramolecular chain that runs along $c$-axis. These chains stack along $a$-axis via N6-H6A...O1 hydrogen bonds forming a two-dimensional supramolecular network (Table 2 and Fig. 2) 
Table 2 Hydrogen bonding geometry for the compound $1\left(\AA,^{\circ}\right)$

\begin{tabular}{|c|c|c|c|c|}
\hline D-H...A & D-H & d(H...A) & $d(D \ldots A)$ & $<$ (DHA) \\
\hline C10-H10B...N4 & 0.96 & 2.57 & $3.177(3)$ & 122 \\
\hline N6-H6B...N5 $5^{\mathrm{i}}$ & 0.86 & 2.27 & $3.085(3)$ & 158 \\
\hline $\mathrm{C} 7-\mathrm{H} 7 \mathrm{~A} \ldots \mathrm{N} 2^{\mathrm{ii}}$ & 0.97 & 2.56 & $3.464(4)$ & 156 \\
\hline N6-H6A...O $1^{\mathrm{iii}}$ & 0.86 & 2.18 & $3.031(4)$ & 172 \\
\hline
\end{tabular}

Symmetry codes : (i) $1-x, 1-y,-z$; (ii) $1-x,-y, 1-z$; (iii) $1+x,-1+y, z$.

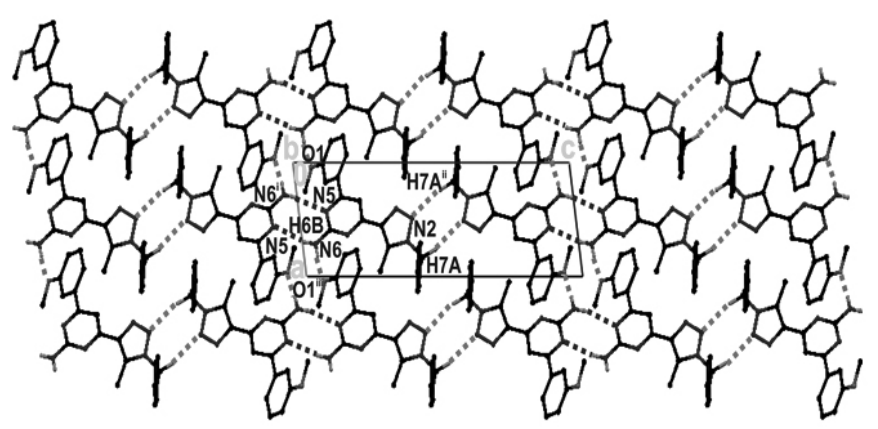

Figure 2: View of two-dimensional supramolecular network down $b$-axis. The $\mathrm{N}-\mathrm{H} \ldots \mathrm{N}, \mathrm{C}-\mathrm{H} \ldots \mathrm{N}$ and $\mathrm{N}-\mathrm{H} . . . \mathrm{O}$ hydrogen bonds are shown as red, blue and green dotted lines, respectively.

\subsection{DFT Calculations}

The first task for the computational work is to determine the optimized geometry of the title compound. The starting coordinates were obtained from $\mathrm{X}$-ray structure determination. The optimized parameters (bond lengths, bond angles) of the compound 1 were obtained using (DFT/B3LYP) method with the $6-311 \mathrm{G}(\mathrm{d}, \mathrm{p})$ basis set. The results are listed in Table 3 and compared with the experimental data for the title compound.

As seen from the Table 3, the agreement between the theoretically calculated and the experimentally obtained structure parameters for the title compound are very good. In view of the bond lengths in Table 3 , most predicted values are longer than experimental ones. We note that the experimental results are for the solid phase and the theoretical calculations are for the gas phase. In the solid state, the existence of a crystal field along with the intermolecular interactions connect the molecules together, which results in the difference in bond parameters between the calculated and experimental values ${ }^{28}$.

When the X-ray structure of the title compound is compared with its optimized counterpart (see Fig. 1), conformational discrepancies are observed. The orientation of the

methoxy phenyl ring of compound $\mathbf{1}$ proved the most notable discrepancy, and is defined with torsion angle N5-C13-C15-C20 $=-40.1(4)^{\circ}$, which is calculated at $-14.453^{\circ}$ for B3LYP/6-311G (d,p) level. As seen from Table 3 , the difference between the X-ray and calculated values for the bond lengths C5-C6, C14-N6 and C18-C19 are $0.0306 \AA, 0.0352 \AA$ and 0.0149 $\AA$, respectively. Similarly, the difference for bond angles C7-N1-C9, N5$\mathrm{C} 14-\mathrm{N} 6$ and $\mathrm{C} 12-\mathrm{C} 13-\mathrm{C} 15$ are $0.803^{\circ}, 1.216^{\circ}$ and $1.57^{\circ}$, respectively. This difference is more not only because of intramolecular C10-H10B...N4 hydrogen bond but also due to intermolecular N6-H6B...N5, C7-H7A...N2, and N6-H6A...O1 interactions. According to experimental and theoretical values, the dihedral angles between triazole and pyrimidine rings are $17.8(1)^{\circ}$ and $1.6^{\circ}$, respectively and also between benzene ring and methoxy phenyl ring are $40.2(2)^{\circ}$ and $64.2^{\circ}$, respectively.

A global comparison was performed by superimposing the molecular skeletons obtained from X-ray diffraction and the theoretical calculations atom by atom (Fig. 3), obtaining RMSE's values of $0.688 \AA$ for (DFT/B3LYP) method with the $6-311 \mathrm{G}(\mathrm{d}, \mathrm{p})$ basis set. This magnitude of RMSE can be explained by the fact that the intermolecular coulombic interaction with the neighbouring molecules are absent in gas phase, whereas the experimental result corresponds to interacting molecules in the crystal lattice.
Table 3 Selected structural parameters by X-ray diffraction and DFT calculations for compound $\mathbf{1}$

\begin{tabular}{|c|c|c|}
\hline Parameters & X-ray & DFT \\
\hline \multicolumn{3}{|c|}{ Bond lengths ( $(\AA)$} \\
\hline C5-C6 & $1.368(5)$ & 1.3986 \\
\hline C18-C19 & $1.386(4)$ & 1.4009 \\
\hline C11-N4 & $1.331(4)$ & 1.3410 \\
\hline $\mathrm{C} 12-\mathrm{C} 13$ & $1.381(4)$ & 1.3964 \\
\hline C14-N6 & $1.335(4)$ & 1.3702 \\
\hline $\mathrm{C} 21-\mathrm{O} 1$ & $1.409(4)$ & 1.4207 \\
\hline N1-N2 & $1.345(3)$ & 1.3589 \\
\hline $\mathrm{N} 2-\mathrm{N} 3$ & $1.299(3)$ & 1.2911 \\
\hline \multicolumn{3}{|c|}{ Bond angles $\left({ }^{\circ}\right)$} \\
\hline $\mathrm{N} 3-\mathrm{C} 8-\mathrm{C} 9$ & $109.0(2)$ & 108.336 \\
\hline C7-N1-C9 & $128.6(2)$ & 129.403 \\
\hline N5-C14-N6 & $117.8(2)$ & 116.584 \\
\hline N1-C9-C10 & $122.2(2)$ & 123.345 \\
\hline N4-C11-C12 & $122.3(2)$ & 121.908 \\
\hline $\mathrm{C} 12-\mathrm{C} 13-\mathrm{C} 15$ & $120.7(2)$ & 122.27 \\
\hline $\mathrm{N} 2-\mathrm{N} 3-\mathrm{C} 8$ & $108.8(2)$ & 109.651 \\
\hline \multicolumn{3}{|c|}{ Torsion angles $\left({ }^{\circ}\right)$} \\
\hline $\mathrm{C} 1-\mathrm{C} 6-\mathrm{C} 7-\mathrm{N} 1$ & 123.1(3) & 130.998 \\
\hline C9-C8-C11-N4 & $18.9(4)$ & 2.002 \\
\hline N3-C8-C11-C12 & $16.2(4)$ & 1.625 \\
\hline N5-C13-C15-C20 & $-40.1(4)$ & -14.453 \\
\hline $\mathrm{C} 12-\mathrm{C} 13-\mathrm{C} 15-\mathrm{C} 20$ & $138.3(3)$ & 164.86 \\
\hline C18-C19-O1-C21 & $169.7(3)$ & 179.878 \\
\hline
\end{tabular}

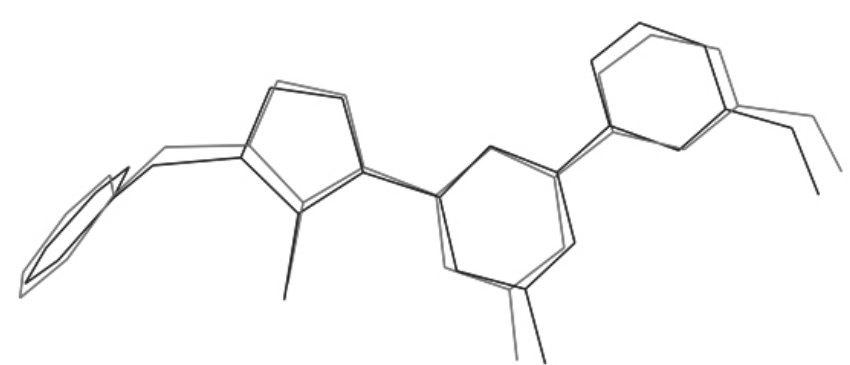

Figure 3: Atom-by-atom superimposition of the calculated structure (blue) and the X-ray structure (red) for compound $\mathbf{1}$

The atomic charge in molecules is fundamental to chemistry. For instance, atomic charge has been used to describe the processes of electronegativity equalization and charge transfer in chemical reactions ${ }^{29,30}$ and to model the electrostatic potential outside molecular surface ${ }^{31-33}$. Mulliken atomic charges calculated at the B3LYP/6-311G(d,p) methods are collected in Table 4. It is worthy to mention that $\mathrm{C} 19, \mathrm{C} 14, \mathrm{C} 13, \mathrm{C} 11$, and $\mathrm{C} 9$ atoms of title compound exhibit positive charges, while other carbon atoms exhibit negative charges. The charge values for Nitrogen N4 and $\mathrm{C} 10$ atoms are -0.4173 and -0.2496 a.u., respectively. The positive atomic charge is obtained for H10B is 0.1435 a.u. However, all the hydrogen atoms exhibit a net positive charge. The presence of large negative charge on $\mathrm{N} 4$ and $\mathrm{C} 10$ atoms and net positive charge on $\mathrm{H} 10 \mathrm{~B}$ atom may confirms the formation of $\mathrm{C} 10-\mathrm{H} 10 \mathrm{~B} \ldots \mathrm{N} 4$ intramolecular interaction in solid forms. 
3.3 Mulliken analysis

Table 4 Mulliken atomic charges of compound 1

\begin{tabular}{|c|c|c|c|}
\hline Atoms & Atomic charges & Atoms & Atomic charges \\
\hline $\mathrm{O} 1$ & -0.3530 & $\mathrm{C} 18$ & -0.0753 \\
\hline N1 & -0.3269 & $\mathrm{C} 19$ & 0.1787 \\
\hline $\mathrm{N} 2$ & -0.0320 & $\mathrm{C} 20$ & -0.0579 \\
\hline N3 & -0.2436 & $\mathrm{C} 21$ & -0.1330 \\
\hline N4 & -0.4173 & H1 & 0.0873 \\
\hline N5 & -0.4098 & $\mathrm{H} 2$ & 0.0975 \\
\hline N6 & -0.4658 & H3 & 0.0992 \\
\hline $\mathrm{C} 1$ & -0.0707 & $\mathrm{H} 4$ & 0.1016 \\
\hline $\mathrm{C} 2$ & -0.0927 & H5 & 0.1129 \\
\hline $\mathrm{C} 3$ & -0.0847 & H6A & 0.2203 \\
\hline $\mathrm{C} 4$ & -0.0912 & H6B & 0.2207 \\
\hline $\mathrm{C} 5$ & -0.0449 & $\mathrm{H} 7 \mathrm{~A}$ & 0.1599 \\
\hline C6 & -0.1300 & $\mathrm{H} 7 \mathrm{~B}$ & 0.1268 \\
\hline $\mathrm{C} 7$ & -0.0167 & $\mathrm{H} 10 \mathrm{~A}$ & 0.1183 \\
\hline C8 & -0.0604 & H10B & 0.1435 \\
\hline C9 & 0.2811 & $\mathrm{H} 10 \mathrm{C}$ & 0.1358 \\
\hline $\mathrm{C} 10$ & -0.2496 & H12 & 0.1122 \\
\hline C11 & 0.1288 & H16 & 0.0955 \\
\hline $\mathrm{C} 12$ & -0.0384 & H17 & 0.0929 \\
\hline $\mathrm{C} 13$ & 0.1702 & H18 & 0.1008 \\
\hline $\mathrm{C} 14$ & 0.4444 & $\mathrm{H} 20$ & 0.1058 \\
\hline $\mathrm{C} 15$ & -0.1356 & $\mathrm{H} 21 \mathrm{~A}$ & 0.1130 \\
\hline $\mathrm{C} 16$ & -0.0569 & $\mathrm{H} 21 \mathrm{~B}$ & 0.1266 \\
\hline $\mathrm{C} 17$ & -0.0997 & $\mathrm{H} 21 \mathrm{C}$ & 0.1119 \\
\hline
\end{tabular}

3.4 Molecular orbital studies

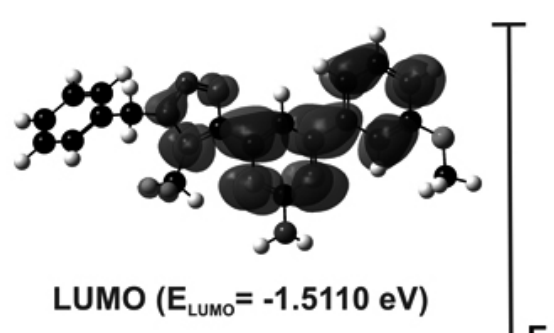

$\mathrm{E}_{\text {номо }}-\mathrm{E}_{\text {LUмо }}=-4.3267 \mathrm{eV}$

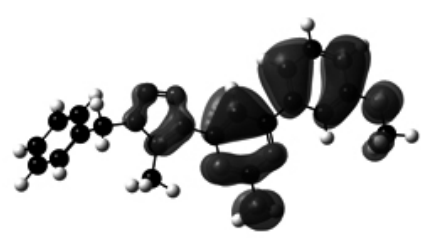

HOMO $\left(E_{\text {номо }}=-5.8777 \mathrm{eV}\right)$

Figure 4: The molecular orbital and energies for the HOMO and LUMO of compound $\mathbf{1}$.
The most widely used theory by chemists is the molecular orbital (MO) theory. The frontier molecular orbitals play an important role in the electronic and optical properties, as well as in UV-VIS spectra and chemical reactions ${ }^{34}$. The DFT calculated electronic absorption spectra, the maximum absorption wavelength corresponding to the electronic transition is from the highest occupied molecular orbital (HOMO) to the lowest unoccupied molecular orbital (LUMO). The frontier molecular orbital energies of the title compound are shown in Fig. 4.

The energy gap between HOMO and LUMO is a critical parameter in determining molecular electrical transport properties ${ }^{35,36}$. The lowest unoccupied molecular orbital (LUMO) energy is $-1.5110 \mathrm{eV}$ and the highest occupied molecular orbital (HOMO) energy is $-5.8777 \mathrm{eV}$. The energy gap of HOMO-LUMO explains the ultimate charge transfer interaction within the molecule, and the frontier orbital energy gap of title compound is found to be $-4.3267 \mathrm{eV}$ obtained at DFT method using $6-311 \mathrm{G}(\mathrm{d}, \mathrm{p})$ basis set. Lower the HOMO-LUMO gap explains the eventual charge transfer interactions taking place within the molecule, which influences the biological activity of the molecule.

\subsection{Chemical reactivity}

Chemical reactivity indices like chemical hardness $(\eta)$, electronegativity $(\chi)$, electronic chemical potential $(\mu)$, and electrophilicity Index $(\omega)$, are calculated using DFT. Chemical hardness is associated with the stability and reactivity of a chemical system. In a molecule, it measures the resistance to change in the electron distribution or charge transfer. On the basis of frontier molecular orbitals, chemical hardness corresponds to the gap between the Highest Occupied Molecular Orbital (HOMO) and Lowest Unoccupied Molecular Orbital (LUMO). Chemical hardness is approximated using equation $\eta=\left(\mathrm{E}_{\text {LUмо }}-\mathrm{E}_{\text {номо }}\right) / 2$, where $\mathrm{E}_{\mathrm{LUмO}}$ and

Table 5 Calculated energy values of compound 1 by B3LYP/6-311G(d,p)

\begin{tabular}{|c|c|}
\hline Basis set & B3LYP/6-311G(d,p) \\
\hline $\mathrm{E}_{\text {номо }}(\mathrm{eV})$ & -5.8777 \\
\hline $\mathrm{E}_{\text {LUмо }}(\mathrm{eV})$ & -1.5110 \\
\hline $\mathrm{E}_{\text {номо }}-\mathrm{E}_{\text {LUмо }}$ gap $(\mathrm{eV})$ & -4.3267 \\
\hline Chemical hardness $(\eta)$ & 2.1634 \\
\hline Chemical potential $(\mu)$ & -3.7144 \\
\hline Electronegativity $(\chi)$ & 3.7144 \\
\hline Electrophilicity index $(\omega)$ & 3.1887 \\
\hline
\end{tabular}

$\mathrm{E}_{\mathrm{HOMO}}$ are the LUMO and HOMO energies, respectively. The larger the HOMO-LUMO energy gap, the molecule will be harder, more stable and less reactive. Table 5 (row 4 ) contains the computed chemical hardness value for title compound.

The concept of electronegativity put forward by Pauling ${ }^{37}$ is defined as "the power of an atom in a molecule to attract electrons towards itself". Higher is the electronegativity of the species, greater is its electron accepting power or rather the electrophilicity. Electronegativity is determined using equation $\chi$ $=-\left(\mathrm{E}_{\text {номо }}+\mathrm{E}_{\text {Luмо }}\right) / 2$, Table 5 (row 6) contains the computed electronegativity values for title compound.

Electronic chemical potential is defined as the negative of electronegativity of a molecule ${ }^{38}$ and determined using equation $\mu=\left(\mathrm{E}_{\text {номо }}+\mathrm{E}_{\mathrm{UUMO}}\right) / 2$. Physically, $\mu$ describes the escaping tendency of electrons from an equilibrium system $^{39}$. The value of $\mu$ for title compound is presented in table 5 (row 5).

Global electrophilicity index $(\omega)$, introduced by Parr, is calculated using the electronic chemical potential and chemical hardness as shown in equation $\omega$ $=\mu^{2} / 2 \eta$. Electrophilicity index measures the propensity or capacity of a species to accept electrons ${ }^{40,41}$. It is a measure of the stabilization in energy after a system accepts additional amount of electronic charge from the environment ${ }^{42}$, 43. The electrophilicity value of the title compound is presented in table 5 (row 7).

The HOMO and LUMO orbital energies are related to gas phase ionization energies $(I)$ and electron affinities $(A)$ of the isomers according to the Koopmans' theorem through equations $A=-\mathrm{E}_{\text {цимо }} I=-\mathrm{E}_{\text {номо. }}$. Electron affinity refers to the capability of a ligand to accept precisely one electron from a donor.

With reference to the paper ${ }^{44}$ the obtained chemical reactivity values of table 5 concludes that the title compound is biologically active. 


\subsection{Molecular Electrostatic Potential}

The Molecular Electrostatic Potential (MEP) is a plot of electrostatic potential mapped onto the constant electron density surface. The MEP has been used primarily for predicting sites and relative reactivity towards electrophilic attack, in studies of biological recognition and hydrogen bonding interactions ${ }^{45}$ 46. The negative electrostatic potential corresponds to an attraction of the proton by the concentrated electron density in the molecule (and is colored in shades of red on the EPS surface), the positive electrostatic potential corresponds to repulsion of the proton by atomic nuclei in regions where low electron density exists and the nuclear charge is incompletely shielded (and is colored in shades of blue). Potential increases in the order red $<$ orange $<$ yellow $<$ green $<$ blue

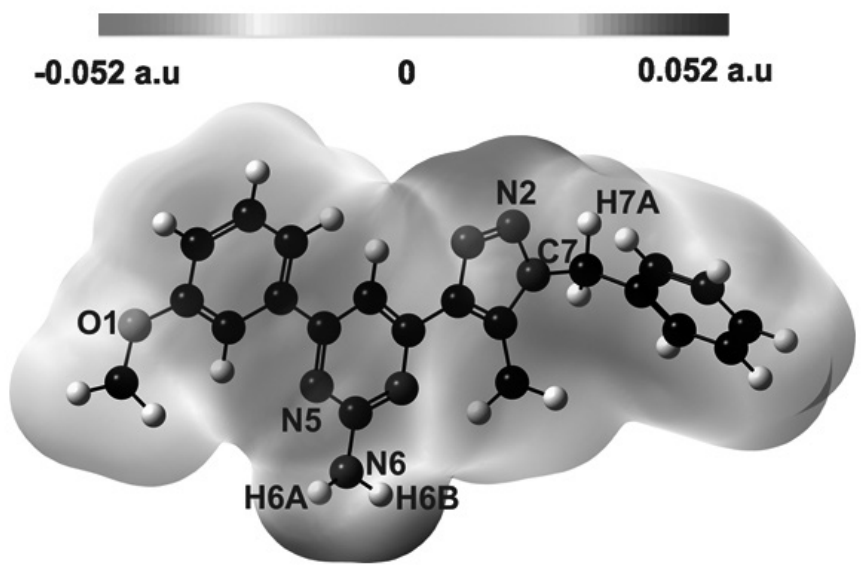

Figure 5: Molecular electrostatic potential map calculated using B3LYP/6-311G(d, p) level.

Fig. 5 shows the molecular electrostatic potential (MEP), was determined using B3LYP/6-311G(d, p) method. The different values of the electrostatic potential at the surface are represented by different colors. As can be seen in Fig. 6, the negative (red) region is localized on the unprotonated atoms of N2, O1 and N5 with a minimum values of $-0.049,-0.033$ and -0.031 a.u. However, positive (blue) region is localized on atom N6 and C7 probably due to hydrogen, with a value of 0.042 and 0.035 a.u., respectively. Therefore, Fig. 5 confirms the existence of an intermolecular C7-H7A...N2, N6-H6A...O1 and N6-H6B...N5, and interactions.

3.7 Thermodynamic properties

The thermodynamics parameters of the compound have also been computed in order to get reliable relations among energetic, structural and reactivity characteristics of the molecules. Knowledge of permanent dipole moment of a molecule allows us to determine molecule's conformation.

Table 6 Thermodynamical parameters of (1) by B3LYP/6-311G(d,p)

\begin{tabular}{|c|c|}
\hline Parameters & Values ( at 298 K) \\
\hline Total energy (Hartree) & -1215.98 \\
\hline Zero point energy $\left(\mathrm{K} \mathrm{cal} \mathrm{mol}^{-1}\right)$ & 239.98631 \\
\hline \multicolumn{2}{|c|}{ Entropy $\left(\mathrm{cal} \mathrm{mol}^{-1} \mathrm{~K}^{-1}\right)$} \\
\hline Rotational constants $(\mathrm{GHz})$ & 0.46522 \\
\hline Total & 0.06233 \\
\hline Translational & 174.985 \\
\hline Rotational & 43.666 \\
\hline Vibrational & 36.512 \\
\hline Dipole moment (Debye) & 94.806 \\
\hline
\end{tabular}

The values of thermodynamic parameters such as zero-point vibrational energy, thermal energy and dipole moment of title compound by DFT method with $6-311 \mathrm{G}(\mathrm{d}, \mathrm{p})$ basis set at $298.15 \mathrm{~K}$ and $1 \mathrm{~atm}$ pressure were calculated and listed in Table 6. From Table 6, the high value of dipole moment of title compound signifies high delocalization of charges, resulting in the formation of relatively loose structured, charge separated species.

The temperature dependence of the thermodynamic properties such as heaf capacity at constant pressure $\left(\mathrm{C}_{p} m\right)$, entropy $\left(\mathrm{S}_{m}\right)$ and enthalpy ( $\mathrm{H}_{m}$ ) for the title compound have been determined by B3LYP/6-311G(d,p) method in temperature range $100-500 \mathrm{~K}$ and listed in Table 7. From Table 7 , it can be observed that these thermodynamic parameters increase with rise of temperature due to the fact that the molecular vibrational thermal energies increase

Table 7 Thermodynamic properties of (1) at different temperatures at B3LYP/6-311G(d,p) level

\begin{tabular}{|c|c|c|c|}
\hline Temperature(K) & $\begin{array}{c}\mathrm{C}^{\circ}, m \\
\left(\mathbf{c a l ~ m o l}^{-1} \mathbf{K}^{-1}\right)\end{array}$ & $\begin{array}{c}\mathrm{S}_{m} \\
\left(\mathbf{~ c a l ~ m o l ~}^{-1} \mathbf{K}^{-1}\right)\end{array}$ & $\begin{array}{c}\mathrm{H}_{m} \\
\left(\mathbf{K c a l ~ m o l}^{-1}\right)\end{array}$ \\
\hline 100 & 37.956 & 106.470 & 242.324 \\
\hline 200 & 64.995 & 142.384 & 247.461 \\
\hline 300 & 94.008 & 174.985 & 255.401 \\
\hline 400 & 122.097 & 206.518 & 266.231 \\
\hline 500 & 144.271 & 236.148 & 279.887 \\
\hline
\end{tabular}

with temperature. The correlation equations between heat capacities, entropies, enthalpy changes and temperatures were fitted by quadratic formulas given in equations. Below, and the corresponding fitting factors $\left(\mathrm{R}^{2}\right)$ for these thermodynamic properties were found to be 0.999 . The temperature dependence correlation graphs are shown in Fig.6.

$$
\begin{array}{lc}
\mathrm{C}_{o p}^{\circ}=10.7175+0.2683 \mathrm{~T}+2.6250 \mathrm{~T}^{2} \times 10^{-5} & \left(\mathrm{R}^{2}=0.9998\right) \\
\mathrm{S}_{p}^{\circ p}=68.9268+0.3875 \mathrm{~T}+1.0953 \mathrm{~T}^{2} \times 10^{-4} & \left(\mathrm{R}^{2}=0.9999\right) \\
\mathrm{H}_{m}^{m}=240.0553+8.4985 \mathrm{~T} \times 10^{-3}+1.4233 \mathrm{~T}^{2} \times 10^{-4} & \left(\mathrm{R}^{2}=0.9999\right)
\end{array}
$$

These equations could be used for further studies on the title compound. For instance, when the interaction of title compound with another compound is studied, these thermodynamic properties could be obtained from the above equation and then can be used to calculate the change in Gibbs free energy of the reaction, which will in turn help to judge the spontaneity of the reaction.

\section{CONCLUSION}

The title compound was synthesized and has been confirmed by NMR and structural (single-crystal X-ray diffraction) techniques. To support the solid state structure, the geometric parameters of the title compound have been calculated using density functional theory DFT (B3LYP) method with the $6-311 \mathrm{G}(\mathrm{d}, \mathrm{p})$ basis sets, and compared with the experimental findings. It was noted here that the experimental results belong to solid phase and theoretical calculations belong to gaseous phase. In the solid state, the existence of the crystal field along with the intermolecular interactions have connected the molecules together, which result in the differences of bond parameters between the calculated and experimental values. The small HOMO-LUMO gap value and the chemical reactivity values shows that the molecule is biologically active. The MEP map confirms the existence of intermolecular $\mathrm{N}-\mathrm{H} . . \mathrm{N}$, $\mathrm{N}-\mathrm{H} \ldots \mathrm{O}$ and $\mathrm{C}-\mathrm{H} \ldots \mathrm{N}$ interactions. The correlations between the statistical thermodynamics and temperature are also obtained. It is seen that the heat capacities, entropies and enthalpies increase with the increasing temperature owing to the intensities of the molecular vibrations increase with increasing temperature.

\section{SUPPLEMENTARY MATERIAL}

CCDC 990693 contains the supplementary crystallographic data for this paper. This data can be obtained free of charge at http://www.ccdc.cam.ac.uk/ data request/cif, by e-mailing data request@ccdc.cam.ac.uk, or by contacting The Cambridge Crystallographic Data Centre, 12 Union Road, Cambridge CB21EZ, UK; fax: +44(0)1223-336033.

\section{ACKNOWLEDGEMENTS}

The authors thank Dr Babu Vargheese, SAIF, IIT, Madras, India, for his help with the data collection. 

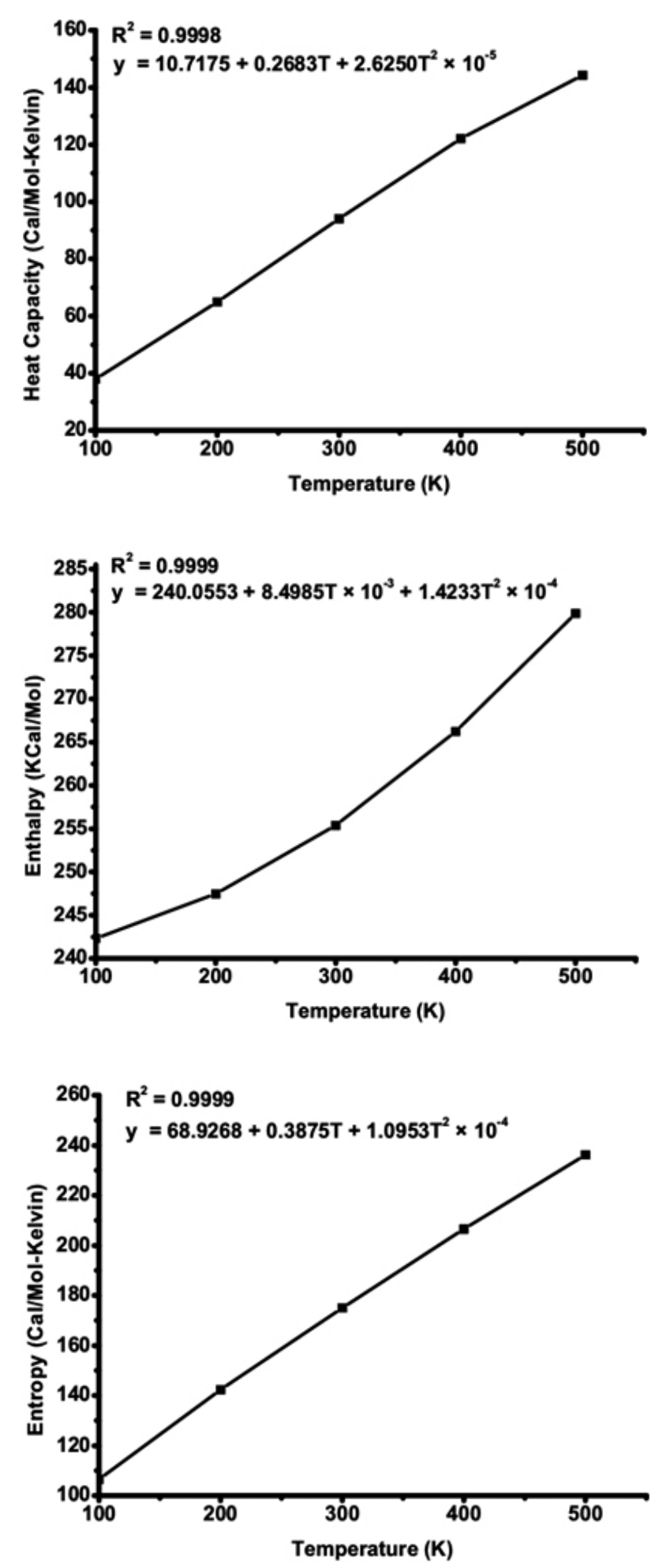

Figure 6: Variation of thermodynamic parameters with temperature for compound 1 .

\section{REFERENCES}

1. J. Morales-Sanfrutos, M. Ortega-Munoz, J. Lopez-Jaramillo, F. HernandezMateo, F. Santoyo- Gonzalez, J. Org. Chem. 73, 7768-7771, (2008)

2. M. J. Genin, D. A. Allwine, D. J. Anderson, M. R. Barbachyn, D. E. Emmert, S. A. Garmon, D. R. Graber, K. C. Grega, J. B. Hester, D. K. Hutchinson, J. Morris, R. J. Reischer, C. W. Ford, G. E. Zurenko, J. C. Hamel, R. D. Schaadt, D. Stapert, B. H. Yagi, J. Med. Chem. 43, 953-970, (2000)

3. D. R. Buckle, C. J. M. Rockell, H. Smith, B. A. Spicer, J. Med. Chem. 29, 2262-2267, (1986)

4. M. J. Giffin, H. Heaslet, A. Brik, Y. C. Lin, G. Cauvi, C. H. Wong, D. E. McRee, J. H. Elder, C. D. Stout, B. E. Torbett, J. Med. Chem. 51, 6263$6270,(2008)$

5. S. Wang, Q. Wang, Y. Wang, L. Liu, X. Weng, G. L. X. Zhang, X. Zhou, Bioorg. Med.Chem. Lett. 18, 6505-6508, (2008)

6. H. I. El-Subbagh, S. M. Abu-Zaid, M. A. Mahran, F. A. Badria, A. M. AlObaid, J. Med. Chem. 43, 2915-2921, (2000)

7. A. R. Trivedi, D. K. Dodiya, N. R. Ravat, V. H. Shah, Arkivoc. XI, 131$141,(2008)$

8. W. Koch, M. C. A. Holthausen A Chemistry Guide to Density Functional Theory, Wiley-VCH, Weinheim, New York, Chichester, 2000

9. R. G. Parr, W. T. Yang Density Functional Theory of Atoms and Molecules, Oxford University Press, New York, 1989

10. S. Nagarajan, P. Shanmugavelan, M. Sathishkumar, R. Selvi, A. Ponnuswamy, H. Harikrishnan \& V. Shanmugaiah, Chin. Chem. Lett. 25, 419-422, (2014)

11. Bruker, APEX-II \& SAINT-Plus (Version 7.06a), Bruker AXS Inc., Madison, Wisconsin, USA, (2004)

12. L. J. Farrugia, J. Appl. Cryst. 32, 837, (1999)

13. G. M. Sheldrick, Acta Crystallogr. A64, 112, (2008)

14. A. L. Spek, J. Appl. Cryst. D65, 148 (2009).

15. L. J. Farrugia, J. Appl. Cryst. 30, 565, (1997)

16. I. J. Bruno, J. C. Cole, P. R. Edgington, M. Kessler, C. F. Macrae, P. McCabe, J. Pearson, R. Taylor, Acta Crystallogr. B58, 389, (2002)

17. A. D. Becke, J. Chem. Phys. 98, 648 (1993)

18. C. Lee, W. Yang, R. G. Parr, Phys Rev B. 37, 785, (1988)

19. R. Ditchfield, W. J. Hehre, J. A. Pople, J. Chem. Phys. 54, 724-728, (1971)

20. R. I. I. Dennington, T. Keith, J. Millam, GaussView (Version 4.1.2.) Semichem Inc., Shawnee Mission, ( 2007)

21. M. J. Frisch, G. W. Trucks, H. B. Schlegel, G. E. Scuseria, M. A. Robb, J. R. Cheeseman, J. A. Jr. Montgomery, T. Vreven, K. N. Kudin, J. C. Burant, J. M. Millam, S. S. Iyengar, J. Tomasi, V. Barone, B. Mennucci, M. Cossi, G. Scalmani, N. Rega, G. A. Petersson, H. Nakatsuji, M. Hada, M. Ehara, K. Toyota, R. Fukuda, J. Hasegawa, M. Ishida, T. Nakajima, Y. Honda, O. Kitao, H. Nakai, M. Klene, X. Li, J.E. Knox, H. P. Hratchian, J. B. Cross, C. Adamo, J. Jaramillo, R. Gomperts, R. E. Stratmann, O. Yazyev, A. J. Austin, R. Cammi, C. Pomelli, J. W. Ochterski, P. Y. Ayala, K. Morokuma, G. A. Voth, P. Salvador, J. J. Dannenberg, V. G. Zakrzewski, S. Dapprich, A. D. Daniels, M. C. Strain, O. Farkas, D. K. Malick, A. D. Rabuck, K. Raghavachari, J. B. Foresman, J.V.Ortiz, Q. Cui, A. G. Baboul, S. Clifford, J. Cioslowski, B. B. Stefanov, G. Liu, A. Liashenko, P. Piskorz, I. Komaromi, R. L. Martin, D. J. Fox, T. Keith, M. A. Al-Laham, C. Y. Peng, A. Nanayakkara, M. Challacombe, P. M. W. Gill, B. Johnson, W. Chen, M. W. Wong, C. Gonzalez, J. A. Pople, Gaussian 03, Revision B.05. Gaussian Inc., Pittsburgh, (2004)

22. A. E. Frisch, A. B. Nielsen, A. J. Holder, Gaussview, Gaussian Inc. Pittsburgh, (2003)

23. D. C. Young, Computational Chemistry: A Practical Guide for Applying Techniques to Real-World Problems (Electronics), John Wiley Sons Inc, New York, (2001)

24. C. C. Huang, F. L. Wu, Y. H. Lo, W. R. Lai, C. H. Lin, Acta Crystallogr. E66, o1690, (2010)

25. J. I. Sarmiento-Sánchez, G. Aguirre, I. A. Rivero, Acta Crystallogr. E67, o1856, (2011)

26. Mujahid Hussain Bukhari, Hamid Latif Siddiqui, Muhammad Ashraf Chaudhary, Tanvir Hussaina, Masood Parvezc, Acta Crystallogr. E64, o963. (2008)

27. J. Bernstein, R. E. Davis, L. Shimoni, N. L. Chang, Angew. Chem. Int. Ed. Engl. 34, 1555-1573, (1995)

28. F. F. Jian, P. S. Zhao, Z.S. Bai, L. Zhang, Struct. Chem. 16, 635-639, (2005) 
29. K. Jug, Z. B. Maksic, In Theoretical Model of Chemical Bonding, Springer, Berlin, (1991)

30. S. Fliszar, Charge distributions and chemical effects, Springer, Berlin, Heidelberg, New York, (1983)

31. P. E. Smith, B. Montgomery Pettitt, J. Am. Chem Soc. 113, 6029-6037, (1991)

32. J. Gao, J. Chem. Phys. 98, 1975-1981, (1993

33. P. Cieplak, P. Kollman, J. Comput. Chem. 12, 1232-1236, (1991)

34. I. Fleming, Frontier orbitals and organic chemical reactions, London:Wiley, (1976)

35. K. Fukui, Science. 218, 747-754, (1982)

36. P. Udhayakala, T. V. Rajendiran, S. Seshadri, S. Gunasekaran, J. Chem. Pharm. Res. 3(3), 610-625, (2011)
37. L. Pauling, The nature of chemical bond, Cornell University Press, Ithaca, (1960)

38. R. G. Parr, R. G. Pearson, J. Am. Chem. Soc. 105, 7512, (1983)

39. P. K. Chattaraj, B. Maiti, J. Am. Chem. Soc. 125, 2705, (2003)

40. A. Vektariene, G. Vektaris, J. Svoboda, ARKIVOC. 7, 311, (2009)

41. R. G. Parr, L. Szentpaly, S. Liu, J. Am. Chem Soc. 121, 1922, (1999)

42. T. Koopmans, Physica. 1, 104, (1933)

43. S. Liu, J. Chem. Sci. 117, 477, (2005)

44. R. Parthasarathi, M. Elango, J. Padmanaban, V. Subramanian, D. R. Roy, U. Sarkar, P. K. Chattaraj, Indian J. Chem, 45A, 111, (2006)

45. J. S. Murray, K. Sen, Molecular Electrostatic Potentials, Concepts and Applications, Elsevier, Amsterdam, pp 7-624, (1996)

46. E. Scrocco, J. Tomasi, Adv. Quant. Chem. 11, 115, (1978) 